Arch. Microbiol. 100, 41-50 (1974)

(C) by Springer-Verlag 1974

\title{
Observations on Chytridiaceous Parasites of Phanerogams
}

\section{A Physoderma on Ranunculus septentrionalis Poir.}

\author{
F. K. Sparrow and Marilyn Shaw Saunders*
}

Botanical Gardens and Biological Station, University of Michigan, Ann Arbor, Michigan

Received July 19, 1974

Abstract. The morphology and reproduction of a Physoderma found on Ranunculus septentrionalis Poir. in Northern Michigan are described. Host range studies indicate it is confined to certain Ranuneulaceae and does not infect hosts from other families in the area which also carry Physoderma infections.

Key words: Physoderma - Parasite - Ranunculus septentrionalis Morphology - Host Range Ranunculacease

The common Swamp Buttercup (Ranunculus septentrionalis Poir.) growing in areass in the vicinity of the University of Michigan Biological Station at Douglas Lake which are subjected to periodic flooding in early spring, is frequently found to be attacked by a Physoderma. Three sites were particularly noteworthy for infected plants. The first (and best) was on mucky ground bordering an old holding pond for logs by the West Branch of the Maple River on Robinson Road, Pellston (May 20, 1964). Another was on Van Creek Road (Van Road) where the stream crosses under the road (30 June, 1964) and a third, found 6 July 1964, on a stream bank in a ditch on west side of U.S. No. 31, 0.7 miles north of Van Road. All were in Emmet Co, Michigan.

On leaves, infected areas were dark brown, those on the lamina being round or oblong, with irregular margins, slightly raised and $0.2-0.5 \mathrm{~mm}$ across (Fig. 1). On the stems, petioles, and stipules they were elongate, and up to $3.0 \mathrm{~mm}$ long by $0.5-1.0 \mathrm{~mm}$ wide (Fig. 2). It was primarily the first-formed basal leaves, undoubtedly submerged in early spring, and young stems, which were infected. Upright axes and their leaves were usually uninfected, as were the floral parts.

\section{Morphology of the Fungus}

By the use of seedlings of Ranunculus septentrionalis immersed in water containing germinating resting spores and free-swimming zoospores as well as by a study of paradermal sections of infected leaves collected in the field and from tubs at the Botanical Gardens, a fairly complete

* Acknowledgement is made to the National Science Foundation (GB 3333) for support of this work. 


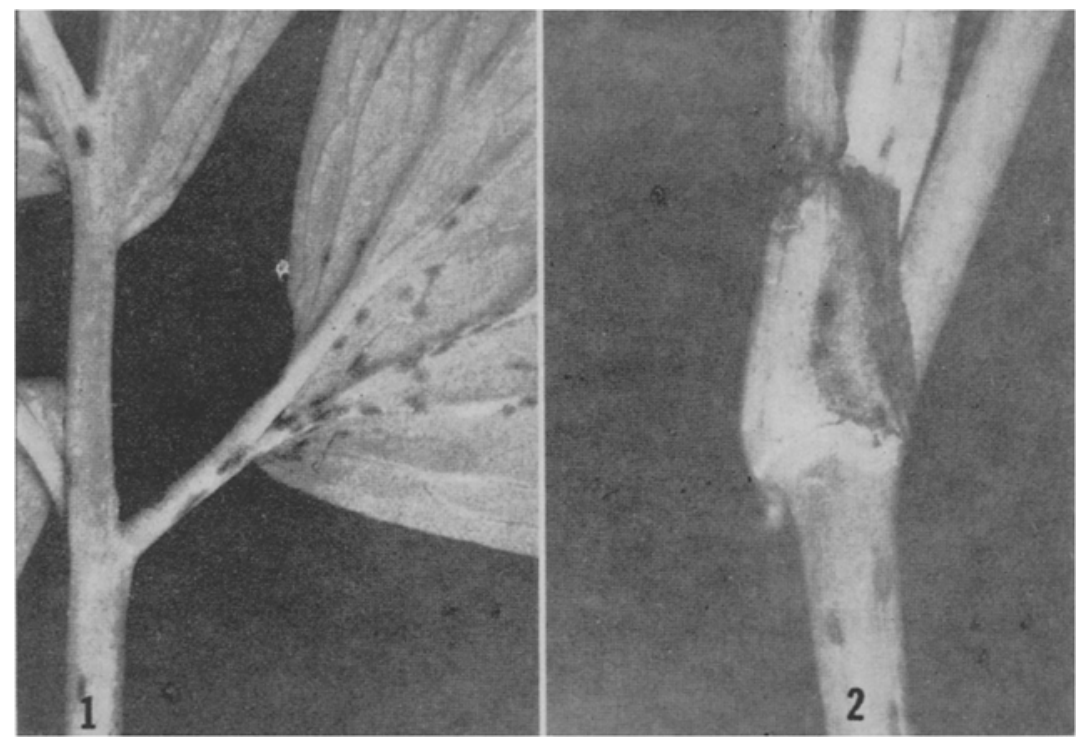

Figs. 1 and 2. Physoderma on Ranunculus septentrionalis. Fig. 1. Back of leaf petiole showing dark pustules of Physoderma infection. Fig.2. Stem and stipule showing scattered infections

picture of germination of resting spores and of both endobiotic and epibiotic phases was obtained.

\section{Germination of the Resting Spores}

The sequence of events in the germination of the resting spores borne on the endobiotic stage of the parasite did not differ from that described in other papers by the senior author and his associates (Sparrow, 1964a and b; Sparrow et al., 1961; etc.) and will not be repeated here. Suffice to say that the resting spore opens by circumcissile dehiscense of a cap of wall material (Figs. 3-5) and there grows from it a thin walled broadly conical sac at the tip of which a papilla is formed (Figs. 6, 7). The contents meanwhile undergo a series of changes which eventuate in the formation of a number of zoospores ("R.S. zoospores") (Fig. 6, 7), each with a prominent oil globule. At discharge, the apex of this sac or so-called "endosporangium" deliquesces and the posteriorly uniflagellate, spherical, $6-7 u \mathrm{~m}$ in diameter zoospores emerge and lie motionless a few minutes at the orifice before assuming individual motility (Fig.8). Zoospores (Fig.9) from a population of resting spores, after an unknown period of motility (probably 3-4 hrs), settle down on host tissue, lose their flagella, encyst, and develop in either of two ways: 1 . to form a new polycentric endobiotic system, or 2. epibiotic sporangia. What governs the mode of development of an individual R.S. zoospore is unknown at present. 


\section{Formation of the Endobiotic System}

The first element of the endobiotic polycentric system established in the host is what has been termed the "primary turbinate cell" (p.t.c.). This receives the contents of the infecting zoospore cyst, save for a small refractive globule (Fig. 10). It soon becomes enlarged $(9-11 \times 10-15 \mu \mathrm{m})$, somewhat broadly pyriform and becomes divided, usually transversely into two unequal cells, the distal one of which is often the larger (Fig. 10). Subsequent development involves the production of one or more delicate unbranched outgrowths which may give rise to another turbinate cell (Fig. 10,a) or more commonly continue into deeper layers of the host and there form new such centers of replication of the thallus. Occasional branching of these delicate rhizoids could be detected (Fig. 11, a).

The fully mature secondary turbinate cells were $17-23 \mu \mathrm{m}$ long and $8-12 \mu \mathrm{m}$ wide. Occasionally they appeared divided or separated by delicate membranes into several cells (Fig.11). It was at the tip of a narrow tubular outgrowth up to $15 \mu \mathrm{m}$ long of one of these cells that the resting spore had its origin (Fig.11,b). A steady increase in size of this rudiment eventuated in the formation of a disproportionately large ellipsoidal, thin-walled structure replete with droplets of various sizes. Occasionally, several haustoria-like tufts of digitations could be found on developing resting spores (Fig. 11, b) but these were not uniformly present. Centripetal thickening of the spore wall was accompanied by the appearance of a faint amber-coloration of the rudiment, a feature which became more pronounced as maturation proceeded. Meanwhile the globules in the contents became like-sized and organized around a large central vacuole.

At full maturity the resting spores were ellipsoidal, $35-\mathbf{2 6 . 2 5} \mu \mathrm{m}$ (long axis) $\times 28-19.25 \mu \mathrm{m}$ (short axis) (av. $29.9 \times 23.8 \mu \mathrm{m}$ ) and varied in number and dimensions in the host cells seemingly according to the size of the latter. The wall was about $2 \mu$ thick and amber-colored.

\section{Epibiotic Stage}

As is generally known, this Rhizophydium-like, monocentric stage derived from certain R.S. zoospores has its reproductive rudiment perched on the outside of the host with its rhizoids developed only in the single epidermal cell beneath it (Fig.14). It should be emphasized that development of this stage takes place concurrently with development of the strongly endobiotic polycentric stage just described, and from the same population of R.S. zoospores.

Early in development of the infecting zoospore, a system of short rhizoids is laid down within the epidermal cell of the host (Fig. 18) rather than a turbinate cell, and this feature at once distinguishes the two 
modes of development (endo- or epibiotic). In development of the epibiotic sporangium the spherical cyst of the zoospore undergoes unequal enlargement, tending to bulge out laterally from beneath a rigid unexpanded part of the wall (Figs. 18-21). This steady lateral enlargement may be equal in opposite directions or slightly biased in one. Upward expansion, however, is never the equal of lateral, and as a consequence, the mature sporangium always has its long axis parallel with the surface of the host on which it rests (Fig.13). Unequal local enlargement of the rudiment also results in occasional "humps", ridges or lobes on the dorsal surface like those found in Physoderma maculare (Sparrow, 1964a) but not so numerous or pronounced (Figs. 14 and 17). When mature, such sporangial rudiments are highly variable in size, ranging from $23-60 \mu \mathrm{m}$ wide by $12-27 \mu \mathrm{m}$ high. The persistent thick-walled part of the unexpanded cyst of the zoospore is usually $7 \mu \mathrm{m}$ in diameter and apical and central on the dorsal surface (Figs. 14 and 17).

Within the host epidermal cell, the rhizoids tend to form a bushy mass of stubby branched elements (Figs.21 and 22). Frequently they are masked by dense host cell contents. They are often seen to arise from a single only slightly expanded endobiotic plexus at the base of the sporangium (Fig. 17).

In preparation for zoospore discharge, the contents undergo a series of protoplasmic changes precisely like those seen in other species of

Figs.3-22. Various stages of Physoderma on Ranunculus septentrionalis. Fig.3. Mature resting spore with line of dehiscence of operculum visible. Figs. 4-8. Stages in germination of resting spore. Fig.9. The R.S. zoospores. Fig. 10. Two stages in establishment of endobiotic system inside host cell. The cyst of infecting zoospore is sessile on the outside of host epidermis. In the right-hand figure the primary turbinate cell is established inside epidermal cell. In left-hand figure the p.t.c. has given rise to another turbinate cell whose distal rhizoid will spread the infection to new host cells. Fig.11. Infected host cells showing turbinate cells rhizoids and resting spores. At $a$ one of the few instances in which branching of tips of rhizoids seen. At $b$ a resting spore with antler-like processes has formed at tip of a tube from a turbinate cell on its left. Several thin-walled immature resting spores are also seen. The inner wall of the resting spores, as found in Fig. 3, has not appeared as yet

Figs.12-22. Epibiotic stage of parasite. Figs. 12 and 13. Mature sporangia perched on epidermal cell nearly ready to discharge. Left-hand sporangium of rare type with 2 discharge papillae. The thick-walled portion of cyst of zoospore wall shown on dorsal surface. Fig. 14. Sporangium in characteristic "ring" stage showing endobiotic apophysis with short rhizoids. Fig.15. Empty sporangium with new sporangium arising by internal proliferation. Fig.16. Zoospores escaping from epibiotic sporangium. Fig.17. Large, somewhat gibbose sporangium. Figs. 18-21. Early stages in development of epibiotic sporangium showing assumption of apical position by thickened part of infecting zoospore wall. Fig. 22. Rhizoidal system of an epibiotic sporangium in an epidermal cell of host. Bar at Figs. 7 is $10 \mu \mathrm{m}$ 

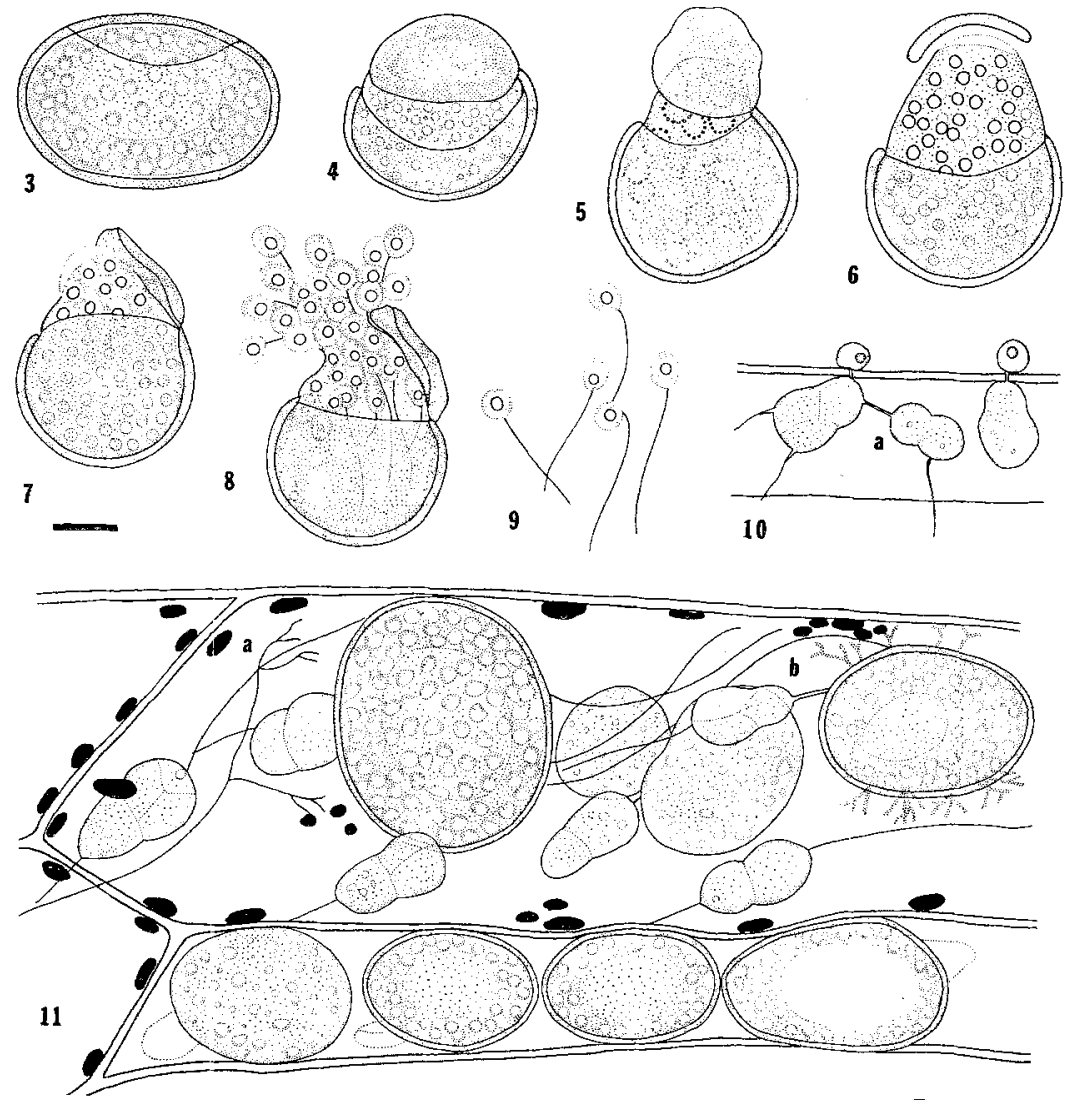

12

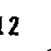

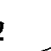

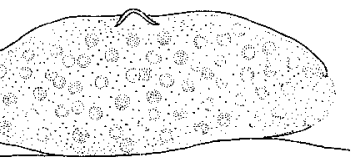

13
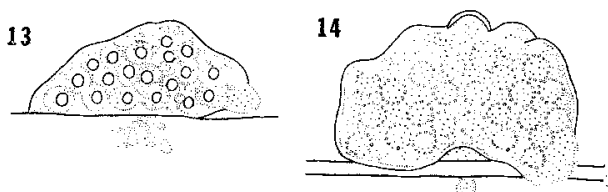
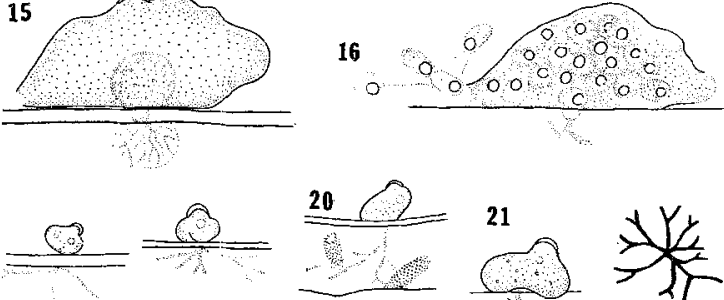

18

19
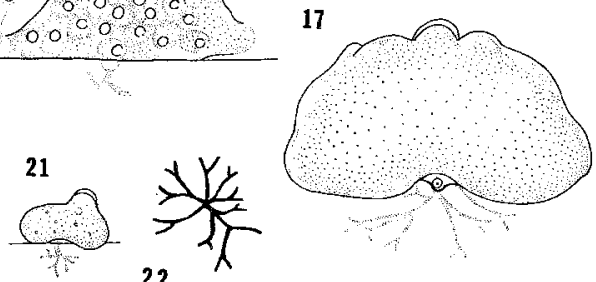

Figs. 3-22 
Physoderma (Sparrow et al., 1961), involving "ring stages" (Fig. 14) ete., and finally yielding a sporangium with a varying number of zoospores each with a spherical colorless refractive body, cleaved out within it (Fig. 13). One (rarely 2) broad discharge papilla is formed at one end of the sporangium. At its dissolution the epibiotic zoospores emerge (Fig. 16), each with an ovoid body, $6-7 \mu \mathrm{m} \times 4 \mu \mathrm{m}$, colorless globule, and single trailing flagellum. No sporangia with orange coloration were seen such as are formed in some Physodermas. No fusions of these zoospores were observed and they appear simply to duplicate the epibiotic stage. Internal proliferation of empty sporangia was common (Fig.15).

\section{Host Range Studies}

Since the Physoderma on Ranunculus septentrionalis was fairly reliable as to germination of its resting spores, some progress was made in testing the host range of this "holobiotroph" (Luttrell, 1974).

The same procedures were used in cross-inoculations as have been described elsewhere (Sparrow and Griffin, 1964) namely, host seedlings or young unexcised parts of established plants (usually the former) were put in contact with R.S. zoospores of the Physoderma swimming in shallow watch glasses of water. Since all sites in nature from which we have collected Physoderma-infected plants have had a history of submergence in rain- or snow-water for considerable periods in the spring, the aforementioned set-up did not impress us as being abnormal; quite the contrary. By this method it was relatively easy with seedlings to follow under the microscope the zoospore in its attempt to penetrate the host, and to follow the progress of the infection when it occurred. Table 1 gives the results of our cross-inoculation trials. The reason for the inclusion of the non-ranunculaceous hosts is indicated later.

From Table 1, the results of our cross-inoculation studies seem to indicate that within the limitations of our methods and the number of trials, our fungus seems confined to Ranunculaceae and, with one exception (Trollius), to Ranunculus. It readily infected its original host. Neither $R$.abortivus nor Trollius yunnanensis have been reported as being infected by Physoderma in nature. We are not satisfied with our negative results on Caltha, since only 2 seedlings were used, the rest being very young leaves. The failure to infect Thalictrum dasycarpum was surprising since Physoderma-infected plants were frequent among infected $R$. septentrionalis at the Pellston site. The production of a few epibiotic sporangia on $T$. polygamum and Anemone rivularis seedlings is of limited significance since this stage could probably not itself overwinter in nature. Both $R$. acris and $R$. pensylvanicus are infected by a Physoderma at the same site, one at which we have not as yet found $R$. septen- 
Table 1. Results of cross-inoculations of certain vascular plants using physoderma on Ranunculus septentrionalis as inoculum

\begin{tabular}{|c|c|c|c|c|c|}
\hline Host & $\begin{array}{l}\text { Country of seed } \\
\text { source }\end{array}$ & $\begin{array}{l}\text { Epibiotic } \\
\text { stage }\end{array}$ & $\begin{array}{l}\text { Endo- } \\
\text { biotic stage }\end{array}$ & $\begin{array}{l}\text { Resting } \\
\text { spores }\end{array}$ & $T / P^{\mathrm{a}}$ \\
\hline Ranunculus abortivus & Mich., USA & + & + & + & $3 / 7$ \\
\hline R.acris & Germany & + & + & $-\mathrm{b}$ & $2 / 5$ \\
\hline R. acris & Mich., USA & + & + & + & $1 / 6$ \\
\hline R. acris & Sweden & + & + & + & $3 / 6$ \\
\hline R. flammula & Great Britain & - & - & - & $6 / 16$ \\
\hline R. flammula & Portugal & - & - & - & $1 / 4$ \\
\hline \multicolumn{6}{|l|}{ R. flammula var. } \\
\hline tiliformis & $\begin{array}{l}\text { Mich., USA } \\
\text { Mich.. USA }\end{array}$ & - & $\overline{1}$ & - & $\begin{array}{l}1 / 6 \\
1 / 3\end{array}$ \\
\hline R. pensylyanicus & $\begin{array}{l}\text { Mich., USA } \\
\text { Sweden }\end{array}$ & $\overline{+}$ & \pm & $\dot{+}$ & $\begin{array}{l}1 / 3 \\
3 / 7\end{array}$ \\
\hline $\begin{array}{l}\text { R. repens } \\
R . \text { sceleratus }\end{array}$ & $\begin{array}{l}\text { Sweden } \\
\text { Great Britain }\end{array}$ & + & $\overline{-}$ & - & $2 / 8$ \\
\hline R. septentrionalis & Mich., USA & + & + & + & $4 / 11$ \\
\hline R.gmelini & Mich., USA & - & + & + & $2 / 6$ \\
\hline Caltha palustris & Mich., USA & - & - & - & $3 / 11$ \\
\hline \multicolumn{6}{|l|}{ Thalictrum } \\
\hline dasycarpum & Mich., USA & - & - & - & $10 / 17$ \\
\hline$T \cdot$ polygamum & Great Britain & + & - & - & $5 / 11$ \\
\hline Anemone rivularis & Great Britain & + & - & - & $3 / 10$ \\
\hline Trollius yunnanensis & Brit. Col., Canada & + & + & + & $2 / 7$ \\
\hline Coptis groenlandica & Ontario, Canada & - & - & - & $2 / 10$ \\
\hline Aquilegia canadensis & Great Britain & - & - & - & $2 / 8$ \\
\hline \multicolumn{6}{|l|}{ Gramineae } \\
\hline Agropyron repens & Mich., USA & - & - & - & $1 / 3$ \\
\hline Phalaris arundinaced & Mich., USA & - & - & - & $1 / 4$ \\
\hline Glyceria striata & Mich., USA & - & - & - & $2 / 6=$ \\
\hline Elymus canadensis & Mich., USA & - & - & - & $1 / 4$ \\
\hline \multicolumn{6}{|l|}{ Alismataceae } \\
\hline Alisma triviale & "Europe" & - & - & - & $1 / 2$ \\
\hline A. plantago-aquatica & Mich., USA & - & - & - & $1 / 4$ \\
\hline \multicolumn{6}{|c|}{ Umbelliferae } \\
\hline Sium suave & Mich., USA & - & - & - & $2 / 6$ \\
\hline S. latifolium & Sweden & - & - & - & $2 / 6$ \\
\hline Cicuta bulbifera & Mich., USA & - & - & - & $1 / 4$ \\
\hline \multicolumn{6}{|l|}{ Rosaceae } \\
\hline Potentilla anserina & Mich,, USA & - & - & - & $3 / 4$ \\
\hline Potentilla anserina & Calif., USA & - & - & - & $3 / 3$ \\
\hline \multicolumn{6}{|l|}{ Scrophulariaceae } \\
\hline \multirow{2}{*}{\multicolumn{4}{|c|}{ Labiatae }} & & $3 / 18$ \\
\hline & Mich., USA & - & - & $\rightarrow$ & $1 / 4$ \\
\hline Lycopus americanus & Mich., USA & - & - & - & $\begin{array}{l}1 / x \\
1 / 6\end{array}$ \\
\hline \multicolumn{6}{|c|}{ Campanulaceae } \\
\hline Lobelia cardinalis & Mich., USA & - & - & - & $2 / 10$ \\
\hline \multicolumn{6}{|l|}{ Asclepiadaceae } \\
\hline Asclepias incarnata & Mich., USA & - & - & - & $1 / 3$ \\
\hline
\end{tabular}

a $T / P=$ Total number trials/Total number of plants or plant parts used.

b Plants died too soon. Fiad immature r.sp. (regard as + ?). 
trionalis. Possibly the same Physoderma is on all 3 hosts but this has not been verified. Most interesting is the failure to infect seedlings of $R$. flammula from two European sources and its variety filaformis (" $R$. reptans L.") from the United States. This would lend support to the distinctiveness of the classical species Physoderma flammulae (Büsgen) de Wild. known thus far only from the resting spore stage.

The non-ranunculaceous hosts included in Table 1 with two exceptions (Sium latifolium and Cicuta bulbifera) were chosen because they are known to be infected by Physodermas in our general study area. Three of these, Lobelia cardinalis, Mimulus ringens, and Lycopus americanus regularly were Physoderma-infected at the same site as was Ranunculus septentrionalis ("U.S. No. 31" north of Pellston). Asclepias incarnata from which a Physoderma has recently been described (Sparrow and Johns, 1970) and Mentha arvensis are (along with Thalictrum dasycarpum) all found with infected $R$. septentrionalis at the Pellston saw mill site. None of these became infected, which also argues for the restriction of our fungus to ranunculaceous hosts.

\section{Discussion}

One of the important objectives of our investigations of Physoderma is to discover features of real significance in distinguishing species.

The morphological features of our fungus on Ranunculus septentrionalis are not very distinctive when compared with many other fully known Physodermas. Particularly is this true of the strongly polycentric endobiotic vegetative system. Its broadly spindle-shaped "turbinate organs" which are usually slightly constricted where the single transverse cross-wall divides it into two nearly equal cells are like those found in Physodermas in R. lobbii (Sparrow, 1968), Potentilla anserina, Sium suave (unpubl.), Asclepias incarnata (Sparrow and Johns, 1970), Acorus calamus (Sparrow, 1964 b), Agropyron repens (Sparrow et al., 1961) and, to a lesser degree, Butomus umbellatus (Sparrow, 1974). Likewise, in the formation of resting spores and their germination, similarity is found with nearly all members of the genus. Size of resting spore, thickness of wall and its color are distinctions which need to be examined more extensively.

Earlier work on a Physoderma on Agropyron repens (Sparrow and Griffin, 1964) clearly indicated that when this fungus was inoculated into various grass hosts size of resting spore varied significantly depending upon the host plant and even its degree of maturity. Furthermore, in Physoderma claytoniana Greene (Sparrow, 1947) significant differences were found in resting spore sizes formed in stems as compared with leaves. One of us (F. K. Sparrow) has in preparation a statistical study of resting spore size not only of Physodermas on Ranunculus species but 
also of Physodermas on other ranunculaceous hosts in our study area. Inasmuch as resting spore size has been the most important morphological feature of the fungus used to distinguish all classical and most modern species of Physoderma the limits of its usefulness in distinguishing taxa should be established.

The epibiotic monocentric sporangial stage is somewhat like that found in P. maculare on Alisma (Clinton, 1902; Sparrow, 1964a) in having a gibbose aspect and in bearing a few dorsal ridges. Closer resemblances are to be found with epibiotic sporangia of $P$. johnsii on Caltha, $P$. paustris on Sium (both, Sparrow, 1961), P. butomi (Sparrow, 1974) and Physodermas on Agropyron (Sparrow et al., 1961), Potentilla anserina (unpublished) and on Asclepias (Sparrow and Johns, 1970). These epibiotic sporangia are highly variable in size even on a small area of host epidermis. Their value in distinguishing taxa will be the subject of a forthcoming paper.

Host specificity, like size of resting spores, has long been cited as an important character in delineating taxa in this genus of obligate parasites. In the Agropyron parasite we (Sparrow and Griffin, 1964) have shown a wide host range within the Gramineae and have also infected a member of the rosaceous genus Potentilla. In our present parasite of Ranunculus septentrionalis cross inoculation trials appear to limit it to growth on species of Ranunculus save for one exception (Trollius). We should like to emphasize again our dissatisfaction with the trials on Caltha palustris and mean to repeat these when occasion offers. This is particularly necessary because of its close morphological similarity to Physoderma johnsii Sparrow on Caltha.

We do not wish to ally our fungus on Ranunculus septentrionalis with classical species on Ranunculaceae ( $P$. vagans Schröt. p.p., P.deformans Rostr., etc.) because nothing is known in these of their epibiotic stages. We think it will prove close to, but not identical, with Physoderma johnsii.

\section{References}

Clinton, G. P.: Cladochytrium alismatis. Bot. Gaz. 33, 49-61 (1902)

Luttrell, E. S.: Parasitism of fungi on vascular plants. Mycologia (N. Y.) 66, 1-15 (1974)

Sparrow, F. K.: Observations on chytridiaceous parasites of phanerograms. III. Physoderma claytoniana and an associated parasite. Amer. J. Bot. 34, 325-329 (1947)

Sparrow, F.K.: Observations on chytridiaceous parasites of phanerogams. X. Notes on some species of Physoderma occurring in the Douglas Lake region of Northern Michigan. Papers Mich. Acad. Sci., Arts, and Lett. 46, 183-194 (1961) Sparrow, F. K.: Observations on chytridiaceous parasites of phanerogams. XIII. Physoderma maculare Wall. Arch. Mikrobiol. 48, 136-149 (1964a)

Sparrow, F. K.: Observations on chytridiaceous parasites of phanerogams. XIV. Physoderma calami. Amer. J. Bot. 51, 958-963 (1964b)

4 Arch. Microbiol., Vol. 100 
Sparrow, K.: Physoderma hydrocotylidis and other interesting phycomycetes from California. J. Elisha Mitchell Sei. Soc. 84, 62-68 (1968)

Sparrow, F. K.: Observations on chytridiaceous parasites of phanerogams. XX. Resting spore germination and epibiotic stage of Physoderma butomi Schroeter. Amer. J. Bot. 61, 203-208 (1974)

Sparrow, F. K., Griffin, J. E.: Observations on chytridiaceous parasites of phanerogams. XV. Host range and species concept studies in Physoderma. Arch. Mikrobiol. 49, 103-111 (1964)

Sparrow, F. K., Griffin, J. E., Johns, R. M.: Observations on chytridiaceous parasites of phanerogams. XI. A Physoderma on Agropyron repens. Amer. J. Bot. 48, 850-858 (1961)

Sparrow, F. K., Johns, R. M.: Observations on chytridiaceous parasites of phanerogams. XVII. Notes on a Physoderma parasite on Asclepias incarnata. Arch. Mikrobiol. 70, 72-81 (1970)

Prof. Dr. F. K. Sparrow

Botany Department

University of Michigan

Ann Arbor, Michigan 48104

U.S.A. 